\title{
A Survey of Comparative Toxicity in the Food Chain of Ciguatera
}

\author{
Takeshi Yasumoto, ${ }^{* 1}$ Raymond Bagnis, ${ }^{* 2}$ Sylvie TheVENIN, ${ }^{* 2}$ \\ and Monique GARCON*2
}

(Received March 9, 1977)

\begin{abstract}
In order to elucidate the transmission of ciguatoxin through the food chain and thus determine the primary source of the toxin, fish and molluscs of various feeding habits were collected from three ciguatera-endemic areas of French Polynesia. The specimens included carnivores, herbivores, surface grazers, coral feeders, sediment feeders, and filter deefers. Despite such diversity in feeding habits, all the fish specimens were more or less toxic by our screening method for ciguatoxin. The molluses were non-toxic. Subsequent tests on the diets of these fish disclosed strong toxicity in a sample consisting of algae and detritus collected from the surface of dead coral of the Gambier Islands. Microscopic observation revealed the presence of a large number of a species of dinoflagellate in this sample. Comparison of similar samples from other places indicated that the dinoflagellate might be the cause of the toxicity.
\end{abstract}

In many islands in tropical and subtropical seas where coral reefs are well developed, it has long been known that a variety of species of fish induces, upon consumption, a peculiar type of disease that is distinct from other fish poisonings such as puffer fish or histaminic poisonings. The name of the illness, ciguatera, is of Caribbean origin. The disease, ichthyosarcotoxism, is not only a medical problem but it is also a problem of nutrition since it limits the use of fish protein. A fat soluble toxin named ciguatoxin has long been regarded to be responsible for the disease. ${ }^{11}$ This toxin has been presumed to be produced by a benthic organism and transferred to fish through the web of food chain. ${ }^{2)}$ However, despite of many efforts to identify the primary source of the toxin, the nature of the toxin elaborator has remained uncertain.

In the present study, samples of fish and molluscs collected from three places of French Polynesia having different histories of endemicity were tested for toxicity. The specimens encompasses herbivores, carnivores, coral feeders, surface grazers, sediment feeder, and filter feeder. All these specimens were suspected to cause ciguatera despite of the diversity in their feeding habits. Their alleged diets were also tested in order to trace back the food chain to the original source.

The present paper deals with the toxicity of the specimens of fish at various trophic levels and the finding of a dinoflagellate in the toxic samples. The possibility that the dinoflagellate is the causative organism is duscussed.

\footnotetext{
*1 Laboratory of Food Hygiene, Faculty of Agriculture Tohoku University, Sendai (安元 健：東 北大学農学部食楬化学科).

*2 Institut de Recherches Mèdicale “Louis Malardè”, Papeete, Tahiti.
} 


\section{Materials and Methods}

Materials Samples were collected at the Gambier Islands in May 1974; at Hao, Tuamotu Islands, in February 1976; and at Popote, Tahiti, in 1976. The names of the samples are given in Tables 1-3. When a sufficient quantity of samples was secured, the flesh, liver, other viscera, and gut contents were tested separately.

Extraction Extraction of ciguatoxin was normally done as follows. A sample $(100 \mathrm{~g})$ was homogenized for $2 \mathrm{~min}$ at room temperature with $300 \mathrm{ml}$ of acetone. After filtration the residue was further extracted twice in a similar manner and the combined acetone solution was concentrated to a syrup. To the syrup was added $30 \mathrm{~m} l$ of water and the toxin was extracted with three $100 \mathrm{~m} l$ portions of diethyl ether. After evaporation of diethyl ether the residue was transferred to a separatory funnel with $25 \mathrm{~m} l$ of $80 \%$ aqueous methanol. The methanolic solution was extracted twice with $50 \mathrm{~m} l$ of hexane and once with $25 \mathrm{ml}$ of hexane. After evaporation of methanol the residue was weighed and used for toxicity tests.

Bioassay method Bioassay was carried out by intraperitoneal injection of serial dilutions of the methanol residue in mice weighing from 15 to $20 \mathrm{~g}$ each. For emulsifying the sample, $1 \%$ solution of Tween 60 was used. Because of the small sample size only two mice were used for each dose. The dilution that kills mice was sought and the minimal lethal dose (MLD) is expressed in $\mu \mathrm{g}$ per gram body weight of mouse $(\mu \mathrm{g} / \mathrm{g}$ ). For ready comparison of the samples of various purities, a total amount of the toxin in the sample is expressed in terms of mouse units (MU), with one mouse unit being defined as the total weight in grams of mice which will be killed by the sample.

Microsocpic observations The following samples were examined under a microscope for phytoflagellates: algae and detritus on the dead corals from the Gambier Islands and $\mathrm{HaO}$, the gut contents of a parrotfish from the Gambier Islands, and the gut contents of unicornfish from two areas of the Gambier Islands (Kamaka and Tenoko).

\section{Results and Discussion}

The results of the toxicity tests are presented in Tables 1-3. The specimens tested in this study include carnivorous fish (moray eel and groupers), sargasso feeder (unicornfish), coral feeder (parrotfish), sediment feeder (mullet), filter feeder (Tridacna), and grazers (surgeonfish and turban shell). Despite the diversity in feeding habits, most of the fish collected at three endemic places were more or less toxic. Even the fish which had no toxicity in flesh contained toxin in the liver, as expected from our previous study on moray eel..$^{3)}$ The molluscs tested in this study were nontoxic although occasional outbreaks of poisoning were attributed to ingestion of the same species. ${ }^{4,5)}$

The fact that fish of a variety of feeding habits bear the same toxin makes it difficult 
Table 1. Toxicity of the specimens collected at Hao, Tuamotu Islands

\begin{tabular}{|c|c|c|}
\hline Specimens & $\operatorname{MLD}(\mu \mathrm{g} / \mathrm{g})$ & MU/g sample \\
\hline Algae and detritus on dead corals (1) & 2110 & 0.9 \\
\hline$\pi$ & 4880 & 0.3 \\
\hline Calcareous alga on dead corals (unidentified) & 1070 & 0.9 \\
\hline Bottom sand & 1700 & 0.08 \\
\hline \multicolumn{3}{|l|}{ Coral: } \\
\hline Millepora sp. & 780 & $<0.4$ \\
\hline Porites sp. & 2300 & 0.5 \\
\hline \multicolumn{3}{|l|}{ Surgeonfish (Ctenochaetus striatus) } \\
\hline Liver & 552 & 12.6 \\
\hline Gut contents (1) & 2930 & $<5$ \\
\hline$" \quad(2)$ & 4000 & 0.6 \\
\hline Flesh & 916 & 3.0 \\
\hline \multicolumn{3}{|l|}{ Parrotfish (Scarus gibbus) } \\
\hline Flesh (1) & 511 & 9.5 \\
\hline$" \quad(2)$ & 1092 & 2.4 \\
\hline$\Rightarrow \quad(3)$ & 225 & 1.9 \\
\hline$n \quad(4)$ & 110 & 18.5 \\
\hline $7 \quad(5)$ & 724 & $<2$ \\
\hline$"$ (6) & 454 & 3.1 \\
\hline$"(7)$ & 295 & 17.2 \\
\hline " (8) & 2625 & $<2$ \\
\hline Liver & 484 & 13.5 \\
\hline Gut contents & 1000 & 6.2 \\
\hline \multicolumn{3}{|l|}{ Moray eel (Gymnothorax javanicus) } \\
\hline Liver & 12.5 & 288 \\
\hline Flesh & 4000 & $<0.2$ \\
\hline \multicolumn{3}{|l|}{ Grouper (Plectropomus leopardus) } \\
\hline Liver & 200 & 14.4 \\
\hline Flesh (1) & 2800 & 2.1 \\
\hline$\Rightarrow \quad(2)$ & 2100 & 2.5 \\
\hline$\Rightarrow \quad(3)$ & 3800 & $<2$ \\
\hline \multicolumn{3}{|l|}{ Porgie (Monotaxis grandoculis) } \\
\hline Flesh (1) & 5200 & $<1$ \\
\hline " (2) & 3836 & $<1$ \\
\hline \multicolumn{3}{|l|}{ Mullet (Crenimugil crenilabis) } \\
\hline Liver & 3035 & 42 \\
\hline Flesh & 1735 & 2.1 \\
\hline Viscera & 1757 & 2.0 \\
\hline \multicolumn{3}{|l|}{ Turban shell (Turbo setosus) } \\
\hline Flesh & 1714 & $<4.5$ \\
\hline Viscera & 4036 & $<0.7$ \\
\hline \multicolumn{3}{|l|}{ Giant clam (Tridacna maxima) } \\
\hline Viscera & 3117 & $<3.1$ \\
\hline
\end{tabular}

to obtain a concrete idea of the toxin elaborator in their diets. However, when the alleged diets of these fish were tested, it was found that algae and the detritus fraction on the dead coral collected at the Gambier Islands showed an outstanding toxicity, as shown in Table 2. Microscopic observation of this toxic sample immediately revealed presence of a large number of a species of dinoflagellate besides other ordinary algae. It was also 
Table 2. Toxicity of the specimens collected at the Gambier Islands

\begin{tabular}{lcc}
\hline \hline \multicolumn{1}{c}{ Specimens } & MLD $(\mu \mathrm{g} / \mathrm{g})$ & MU/g sample \\
\hline Algae and detritus on dead corals collected in 1974 & 470 & 1.6 \\
Algae and detritus on dead corals collected in 1975 & 7.6 & 67.5 \\
Calcareous alga (unidentified) & 1110 & 0.4 \\
Parrotfish (Scarus gibbus) & & \\
$\quad$ Liver & 1500 & 6.0 \\
$\quad$ Gut contents & 1000 & 1.1 \\
$\quad$ Flesh & 330 & 2.5 \\
Grouper (Epinephelus fuscoguttatus) & & \\
$\quad$ Flesh & 560 & 5.0 \\
Grouper (Plectropomus leopardus) & & \\
$\quad$ Flesh & 860 & 2.5 \\
Unicornfish (Naso unicornis) & & \\
$\quad$ Gut contents (Tenoko Island) & 1430 & 3.7 \\
Gut contents (Kamaka Island) & 360 & 20.0 \\
\hline
\end{tabular}

Table 3. Toxicity of the specimens collected at Popoti, Tahiti

\begin{tabular}{lcc}
\hline \multicolumn{1}{c}{ Specimens } & MLD $(\mu \mathrm{g} / \mathrm{g})$ & MU/g sample \\
\hline Algae and detritus on dead corals & 517 & 1.4 \\
Calcareous alga (unidentified) & 746 & 0.4 \\
Calcareous alga (Pavona distans) & 1180 & 1.0 \\
Sargassum (unidentified) & 920 & $<0.8$ \\
Bottom sand & 1000 & 0.006 \\
Surgeonfish (Ctenochaetus striatus) & & \\
$\quad$ Liver & 1000 & 16.2 \\
$\quad$ Gut contents & 1120 & 8.5 \\
$\quad$ Flesh & 420 & $<1.8$ \\
Moray eel (Gymnothorax javanicus) & 18 & 1000 \\
$\quad$ Liver & & \\
\hline
\end{tabular}

found that only highly toxic sample contained the dinoflagellate in quantity, while similar samples of low toxicity collected at other places contained few or no dinoflagellate specimens. Another finding supporting the correlation between the toxicity and the dinoflagellate was obtained when the gut contents of unicornfish were examined. The dinoflagellate was present in the gut contents of fish from the toxic area (Kamaka) but was absent in the gut contents of fish from the area of low toxic endemicity (Tenoko). On the other hand, microscopic observation of the gut contents of the parrotfish and surgeonfish could not confirm the presence of the dinoflagellate. However, the appearance of the gut contents suggested that the failure in detecting the dinoflagellate in these species might be attributed to its digestion by the fish rather than its exclusion from the normal diet.

The finding of the dinoflagellate may be regarded as especially important not only because its presence seems correlated to toxicity but because it supported two previous predictions. In our previous paper ${ }^{6)}$ we predicted that a dinoflagellate might be the causa- 
tive organism in ciguatera. The prediction was based on the fact that a toxin first found in C. striatus and named maitotoxin after the Tahitian name "maito" for the fish resembled closely the products of a dinoflagellate, Prymnesium parvum. Our another prediction ${ }^{7)}$ was that the causative organism could not be an ordinary alga such as blue green alga because the chlorophyll concentration of the toxic gut contents of parrotfish was very low.

The dinoflagellate is tentatively identified as Diplopsalis sp. nov by Dr. R. ADACHI, Mie University. Further investigation is being done to prove the relationship between Diplopsalis sp. nov and ciguateric toxicity.

\section{Reference}

1) P. J. Scheuer, W. Takahash, J. Tsutsumi, and T. Yoshida: Science, 155, 1267-1268 (1967).

2) T. Yasumoto, Y. Hashimoto, R. Bagnis, J. E. Randall, and A. H. Banner: This Bull., 37, 724 734 (1971).

3) T. Yasumoto and P. J. Scheuer: Toxicon, 7, 273-277 (1969).

4) T. Yasumoto and K. KANNo: This Bull., 42, 1399-1404 (1976).

5) R. BAGNIs: Bull. Soc. Path. exo., 60 580-592 (1967).

6) T. Yasumoto, J. P. Vernoux, and R. Bagnis: This Bull., 42, 359-365 (1976).

7) T. Yasumoto, I. Nakajma, E. Chungue, and R. Bagnis: ibid., 43, 69-74 (1977). 